УДК 378.4(477.72)

DOI: $\underline{10.35619 / \text { iiu.v1i14.396 }}$

Федясва Валентина

доктор педагогічних наук, професор, професор кафедри педагогіки, психології й освітнього менеджменту імені проф. Є. Петухова

Херсонського державного університету,

м. Херсон, Україна

ORCID: 0000-0002-8658-1875

e-mail: Valentina.Fediaieva@gmail.com

Чабан Олена

кандидат педагогічних наук, доцент, доцент кафедри теорії та методики

дошкільної та початкової освіти

Херсонського державного університету,

м. Херсон, Україна

ORCID: 0000-0001-7494-1223

e-mail:mriya2211@ukr.net

\title{
НАУКОВИЙ ОСЕРЕДОК ВСЕУКРАЇНСЬКОЇ АСОЦІАЦІЇ ВАСИЛЯ СУХОМЛИНСЬКОГО В ХЕРСОНСЬКОМУ ДЕРЖАВНОМУ УНІВЕРСИТЕТІ: СТАНОВЛЕННЯ, ЗДОБУТКИ, ПЕРСПЕКТИВИ РОЗВИТКУ
}

Анотація. У статті проаналізовано діяльність наукового осередку Всеукраїнської асоціації Василя Сухомлинського в Херсонському державному університеті, висвітлено його здобутки та перспективи розвитку. Авторами вивчено архівні матеріали кафедр педагогіки та педагогічної майстерності університету, що фіксують активізацію інтересу до спадщини Василя Сухомлинського вже в 70-80-тих рр. XX ст. Мета публікації полягає в розкритті історії становлення осередку Всеукраїнської асоціації Василя Сухомлинського - кафедри педагогіки, психології й освітнього менеджменту імені проф. Є. Петухова, його напрацювання та визначення перспектив його розвитку у системі підготовки майбутніх учителів; проведенні подальших наукових досліджень спадщини Василя Олександровича та втілення його ідей в умовах сьогодення. Її реалізація спирається на аналіз наукового доробку студентів, аспірантів, докторантів, викладачів кафедри, присвяченого теорії та практиці навчання та виховання дітей за В. Сухомлинським, який знайшов своє найбільш повне відображення в напрацюваннях Всеукраїнської асоціації Василя Сухомлинського. У публікації акцентовано, що системному й більш масштабному вивченню спадщини В. Сухомлинського, у такий спосіб й розвиткові сухомлиністики, сприяла активна наукова діяльність студентів, аспірантів й докторантів. Завдяки виконанню грунтовних наукових робіт (у формі кандидатських та докторських дисертацій) ними було звернуто більше

(C) Федясва В., Чабан О., 2021 


\section{Інноватика у вихованні. Випуск 14. 2021.}

уваги педагогічній персоналії та вивченню практичного досвіду В. Сухомлинського в контексті тогочасних освітніх реалій. Всеукраїнською асоціацією Василя Сухомлинського за участі викладачів Херсонського державного університету проведено три масштабних наукових заходи: XVI Всеукраїнські педагогічні читання «Василь Сухомлинський у діалозі 3 сучасністю: ціннісні виміри в освіті» (2009), XXII Всеукраїнські педагогічні читання «Василь Сухомлинський у діалозі з сучасністю: виховуємо культуру потреб особистості» (2015) та Всеукраїнський освітній форум «Нова українська школа - діалог з В. Сухомлинським» (2018).

Ключові слова: сухомлиністика, асоціація, педагогічні читання, педагогічна спадщина, науковий осередок.

Постановка проблеми. Сьогодення висуває перед педагогічними працівниками високі вимоги до реалізації освітніх завдань, співзвучних 3 особливостями розвитку сучасного суспільства. Такий стан речей потребує перебудови системи підготовки майбутніх учителів 3 урахуванням інноваційних технологій, наповнення змісту освіти сучасним знанням із опертям на історичний досвід. Саме 3 цих позицій законодавча база України в галузі освіти, зокрема Закон України «Про вищу освіту» (2014), Закон України «Про освіту» (2018), Концепція Нової української школи (2016), визначають, що підвищення результативності підготовки вчителів та вихователів до виконання своїх професійних обов'язків не лише базується на втіленні нових засобів і підходів до визначення мети та змісту вищої педагогічної освіти, але й з урахуванням історичних напрацювань вітчизняного шкільництва, спадщини відомих українських учених, педагогів-практиків, як-от виховання особистості на засадах дитиноцентризму, любові, поваги, партнерства, урахування інтересів i потреб кожного учня. Саме на цих засадах й була побудована педагогічна система В. Сухомлинського, зреалізована ним у Павлиській школі на Кіровоградщині й визнана світовою науково-педагогічною спільнотою.

Теоретичні напрацювання Василя Сухомлинського, робота керованої ним авторської школи розглядаються й презентуються освітянами в умовах сьогодення через досить широкий спектр проблем, які постають щоденно перед учителями, батьками, організаторами освіти в освітньому процесі, у роботі з дітьми в сім’і, у підготовці майбутнього педагога тощо.

Аналіз останніх досліджень 3 проблеми. Слід зазначити, що окресленим у публікації питанням присвячено праці відомих вітчизняних учених-сухомлиністів: I. Беха, А. Богуш, В. Кузя, М. Пентилюк, О. Петренко, Г. Пустовіта, О. Савченко, О. Сухомлинської та ін. Вони перебувають постійно у полі зору Всеукраїнської асоціації Василя Сухомлинського. Чільне місце в їі роботі займає діяльність кафедр педагогічного спрямування закладів вищої освіти України різного рівня та типу. Насправді вони є первинними науковими осередками цієї громадської організації - регіональними центрами вивчення та втілення ідей Василя Олександровича в практику сучасних закладів освіти. На сьогодні їх внесок у діяльність цієї організації не розглядається. Однак 


\section{Інноватика у вихованні. Випуск 14. 2021.}

роль первинних наукових об’єднань і їх значущість в реалізації ідей В. Сухомлинського в системі діяльності кожного окремо взятого університету практично не розкрита, що і визначило тему публікації.

Тому, мета наукового пошуку - розкриття історії становлення, досягнення та визначення перспективних ліній розвитку наукового осередку кафедри педагогіки, психології й освітнього менеджменту імені проф. Є. Петухова, зокрема у розгляді системи підготовки майбутніх учителів за В. Сухомлинським; проведенні подальших наукових досліджень спадщини, діяльності Василя Олександровича в освітніх закладах в умовах сьогодення. Ця мета буде реалізовуватись через аналіз теорії та практики навчання та виховання дітей за В. Сухомлинським студентами, аспірантами, докторантами, викладачами кафедри, який знайшов своє найбільш повне відображення в напрацюваннях Всеукраїнської асоціації Василя Сухомлинського.

Виклад основного матеріалу дослідження. Заснування тридцять років тому Всеукраїнської асоціації В. Сухомлинського в Україні було досить знаковим, їі мета, завдання, форми роботи мали велике значення для удосконалення освітнього процесу в закладах освіти України 3 урахуванням напрацювань учених-сухомлиністів 3 питань підготовки майбутніх учителів. Утілення його спадщини у цю систему, зокрема в Херсонському державному університеті, сприяло наповненню змісту навчальних програм, лекційних курсів, практики, різних форм науководослідної роботи з педагогіки, історії педагогіки, актуальними ідеями формування майстерності майбутнього вчителя за відомими працями В. Сухомлинського, долучення до цих форм роботи студентів, аспірантів, учителів шкіл, вихователів дошкільних та позашкільних закладів освіти. У цей період відбулося розширення наукових досліджень у галузі педагогічних наук як в цілому у незалежній Україні, так і в кожному університеті, зокрема активної підготовки молодих науковців в аспірантурі та докторантурі. У цей час на кафедрі педагогіки, психології й освітнього менеджменту імені проф. С. Петухова була відкрита аспірантура та докторантура, в якій за період функціонування з 1992 до 2020-тих р.p. здобули ступінь кандидата і доктора педагогічних наук відповідно 76 i 12 осіб. Аналіз цих досліджень засвідчив, що в більшості з них було вивчення спадщини вітчизняних учених у контексті історичної ретроспективи, посилення уваги до обгрунтування можливостей використання практичного досвіду В. Сухомлинського в освітніх закладах різного типу.

Ці дві складові стали провідними чинниками у послідовній, системній роботі кафедри педагогіки, психології та освітнього менеджменту імені проф. С. Петухова Херсонського державного університету з поглибленого аналізу теоретичних та практичних напрацювань відомого українського вченого, директора Павлиської школи Василя Олександровича Сухомлинського, під кутом зору розробки науково-методичного забезпечення викладання педагогічних дисциплін 3 метою успішної підготовки вчителя в системі неперервної освіти. 


\section{Інноватика у вихованні. Випуск 14. 2021.}

Ця робота здійснювалася як у процесі викладання навчальних дисциплін «Педагогіка», «Історія педагогіки», «Теорія та методика організації виховної роботи в закладах освіти», так і у науково-дослідній роботі студентів, викладачів, аспірантів, докторантів.

Аналіз архівних матеріалів кафедр педагогіки та педагогічної майстерності ХДУ в 70-80-тих рр. ХХ ст. дає можливість стверджувати, що вивчення й дослідження спадщини В. Сухомлинського в університеті (тогочасному педагогічному інституті) як окремого напряму наукового пошуку та використання у підготовці майбутніх учителів, має свою етапність, свої форми й методи реалізації як в освітньому процесі, так і в наукових заходах. Дослідження показало, що підсумком такої діяльності цього періоду стало проведення в жовтні 1988 року педагогічним інститутом обласної науково-практичної конференції, присвяченої 70річчю від Дня народження вченого «В. О. Сухомлинський - видатний радянський педагог - мислитель й гуманіст» (Херсон, 1988) (Программа областной научно-практической конференции, 1988, 10с.). На ній обговорювалося широке коло питань 3 використання його творчої спадщини кожною кафедрою інституту у підготовці вчителя та співпраці зі школами області з підвищення ефективності організації навчальновиховного процесу в інституті та школах. Про це свідчать, наприклад, такі доповіді: «В. О. Сухомлинський - учитель й про учителя» (Кондратенко Г. М.), «В. О. Сухомлинський про формування в учнів естетичного ставлення до природи в процесі сільськогосподарської праці» (Бутенко Н. І.), «Підготовка молодого покоління колективістів у творчості В. Сухомлинського й досвід сучасної школи» (Петухов Є. І.), «B. О. Сухомлинський про самоосвіту» (Нусінова Ж. Н.), «В. О. Сухомлинський про роль народного слова в естетичному вихованні учнів» (Пентилюк М. І.). У них учені наголошували на важливості використання спадщини Василя Олександровича у підготовці вчителя. Загалом на секційних засіданнях обговорювались питання за двома напрямами:

1. Педагогічна спадщина В. О. Сухомлинського й проблеми сучасної середньої школи;

2. В. О. Сухомлинський про підготовку вчителя й удосконалення його майстерності.

Аналіз доповідей та виступів учасників на конференції засвідчив, що всі вони мали конкретні пропозиції з використання напрацювань Василя Олександровича у підготовці майбутнього вчителя. Особливо цінним було те, що активну участь в обговоренні цих питань брали і студенти, i викладачі, і вчителі. При цьому кожен з факультетів (філологічний, фізикоматематичний, загальнотехнічний, початкового навчання) виокремлював особливі шляхи й можливості використання спадщини В. Сухомлинського у підготовці вчителя фізики, математики, загальнотехнічних дисциплін, іноземної мови, української мови й літератури, початкової школи та ін. Такий підхід - вивчення ідей, практичного досвіду з питань організації 


\section{Інноватика у вихованні. Випуск 14. 2021.}

навчально-виховного процесу в Павлиській школі відповідно до професійної спеціалізації майбутнього вчителя характеризує і нинішні підходи до роботи зі студентами. Важливо, аби кожен студент засвоїв ці знання та успішно використовував їх як у процесі навчання, так i виховання, в урочній та позаурочній діяльності відповідно до навчального предмета. Усі вони повинні були засвоїти головне - тільки любов до дитини принесе успіх у роботі. Саме таке ставлення до учнів кожним днем свого життя підтверджував В. Сухомлинський.

Розвиткові сухомлиністики в університеті сприяло й проведення конкурсів студентських наукових робіт як на рівні інституту, так i всеукраїнському. Аналіз архівних матеріалів Херсонського державного університету 3 цих питань засвідчив, що вперше до такого конкурсу студенти долучились у 1999 році і теми їх досліджень були різноплановими, відповідали науковим інтересам, давали їм можливість знайти відповідь на хвилюючі питання в майбутній діяльності (Бабич Мар'яна «Педагогічна майстерність вчителя в педагогічній спадщині В. Сухомлинського», Сараєва Олена «Питання індивідуалізації навчання в педагогічній спадщині В. Сухомлинського», Бутенко Людмила «Естетичне виховання учнів за спадщиною В. Сухомлинського»). Усі вони були студентками факультету української філології, їхні роботи вирізнялися глибиною наукового пошуку; практичною спрямованістю; творчістю; захопленням життям, діяльністю, ідеями вченого, що дало поштовх Олені Сараєвій і Людмилі Бутенко надалі успішно захистити дисертації на здобуття наукового ступеня кандидата педагогічних наук.

Така робота зі студентами, аспірантами, викладачами в кінці XX - на початку XXI ст. стає системною, грунтовною, послідовною і практично входить окремим напрямом в структуру уже існуючої на той час Всеукраїнської асоціації імені Василя Сухомлинського. Також традиційними в університеті стали науково-практичні конференції, на яких розглядались актуальні освітні проблеми і за відповіддю на них викладачі університету звертались до В. Сухомлинського, чому сприяла робота Всеукраїнської асоціації, рада якої визначала кожного року одну із малодосліджених проблем, що була обгрунтована й зреалізована в доробку Василя Олександровича.

Отже, дослідження дає можливість стверджувати, що саме в цей період (2000 р.) відбувається становлення наукового осередку Всеукраїнської асоціації В. Сухомлинського на кафедрі педагогіки (сьогодні кафедра педагогіки, психології й освітнього менеджменту імені проф. С. Петухова Херсонського державного університету).

Знаковою для подальшої роботи нашого осередку стала участь у VIII Всеукраїнських педагогічних читаннях «В. О. Сухомлинський і сучасність: особистісно-орієнтована шкільна освіта» (2001) студентки факультету української філології Олени Сараєвої (Чабан) у 2001 році в м. Одеса. Ці читання стали визначальними для успішної наукової долі як Олени Вікторівни (на сьогодні кандидата педагогічних наук, доцента), так і 


\section{Інноватика у вихованні. Випуск 14. 2021.}

об'єднання викладачів кафедри, студентів, аспірантів, докторантів навколо сухомлиністики, їхня широка участь у проведенні щорічних педагогічних читань та втіленні ідей Василя Сухомлинського у практику підготовки майбутнього вчителя в університеті.

Виконана робота Сараєвої Олени за темою «Педагогічна система Василя Сухомлинського у дослідженнях вітчизняних учених» (2007р.) (Сараєва, 2007, 250 с.) дала можливість розробити: науково-методичне забезпечення вивчення студентами - майбутніми вчителями спадщини вченого; обгрунтувати методичні рекомендації, підготувати бібліографічний покажчик і виокремити ті змістові лінії, які є важливими й значущими для кожного факультету, зокрема з урахуванням такої складової, як професійно орієнтована (Федяєва, Сараєва, 2006, 144 с).

Тож, на кафедрі було визначено особливості шляхів використання спадщини В. Сухомлинського при підготовці вчителів літератури, мови, математики, хімії, біології, історії, початкової освіти тощо (Федяєва, Сараєва, 2006, 144 с).

Багато конкретних відповідних форм роботи прослідковується, коли аналізувати матеріали численних всеукраїнських педагогічних читань, проведених Асоціацією. Адже різноманітні теми дали можливість глибше розкрити, вивчити й обгрунтувати актуальні, конкретні шляхи втілення завдань навчання, виховання, освіти дітей та молоді за В. Сухомлинським. Тим більше, що викладачі кафедри, готуючись до участі в них, також проводили дослідження, а результати презентували колегам, висвітлюючи досвід університету. Як підтвердив тематичний аналіз матеріалів всеукраїнських педагогічних читань, викладачами кафедри упродовж усього періоду було опубліковано 89 статей за доповідями і виступами на секційних засіданнях, читань, що розкривали різні аспекти педагогічної спадщини й діяльності В. Сухомлинського.

Слід наголосити, що одним із напрямів популяризації сухомлиністики на міжнародному рівні стала участь викладачів кафедри у міжнародних наукових заходах. Так, перебуваючи в Китаї з офіційною делегацією, В. Федяєва значно розширила межі спілкування на міжнародному рівні і дала можливість викладачам кафедри познайомитися, зокрема iз практикою використання ідей Василя Олександровича в Китаї, а також донести до китайських викладачів та науковців шляхи використання спадщини відомого вченого в системі підготовки майбутніх учителів через участь у наукових конференціях в Пекінському педагогічному університеті у Національній академії педагогічних наук та Чанжонському університеті. Дослідниця виступила із доповідями: 1) «Педагогічна культура батьків у науковій спадщині Василя Сухомлинського» (2012р.) та 2) «Використання спадщини В. Сухомлинського у підготовці майбутнього вчителя» (2017р.).

Також важливими для роботи кафедри є дотичність викладачів університету до європейського об'єднання дослідників спадщини Й. Ф. Гербарта в контексті розгляду спадщини українських та 


\section{Інноватика у вихованні. Випуск 14. 2021.}

європейських учених в умовах сьогодення. Такі конференції дають можливість розкрити особливості становлення вітчизняної педагогіки, презентувати їх спадщину в європейській науковій спільноті, про що свідчить виступ на одній із них Федяєвої В. Л. і Гоштанар І. В. 3 доповіддю «Освіта вчителів в системі Гербарта й Сухомлинського: порівняльний аналіз» (Федяєва, Гоштанар, 2016).

Новим змістом роботу кафедри наповнили заходи 3 підготовки й проведення всеукраїнських педагогічних читань у Херсонському державному університеті: 1) «В.О.Сухомлинський у діалозі з сучасністю: ціннісний виміри в освіті» (2009 р.) та 2) «В. О. Сухомлинський у діалозі з сучасністю: виховуємо культуру потреб особистості» (2015 р.) та Всеукраїнського освітнього форуму «Нова Українська школа - діалог з В. О. Сухомлинським» (2018р.). До їх організації та проведення долучились безпосередньо всі факультети, кафедри, наукові структурні підрозділи, студентство, що дало можливість обговорити теоретичні проблеми за заявленими темами, а також презентувати досвід університету з використання спадщини В. Сухомлинського в сучасному освітньому процесі. Особливо необхідно відзначити, що велике значення в таких читаннях посідає розгляд питань щодо втілення ідей Василя Сухомлинського в кожному закладі освіти області. Готуючись до розкриття теми «Василь Сухомлинський і Херсонщина», ми об’єднали зусилля науковців, учителів, студентів навколо сухомлиністики, зосередившись на перспективних проблемах реалізації його спадщини на рівні кожного типу навчального закладу. Також необхідно підкреслити, що велике значення для колективу університету мала участь у таких читаннях членів бюро Асоціації, зокрема колишньої голови Олександри Яківни Савченко та доньки Василя Сухомлинського - академіка Ольги Василівни Сухомлинської, які безпосередньо зустрічалися 3 викладачами, студентами, аспірантами. Такі зустрічі є надзвичайно важливими, адже вони дають можливість побачити нові грані життя та діяльності В. Сухомлинського, а також познайомити відомих науковців із досвідом роботи з практичного втілення ідей великого вченого-педагога в практику підготовки майбутніх фахівців. При цьому необхідно підкреслити значущість таких форм роботи, як живе спілкування відомих учених зі студентами, аспірантами, учителями, що дає можливість на практиці побачити успіхи й прорахунки кафедри у вирішенні нагальних освітніх питань. Зокрема, викладачі та аспіранти кафедри долучилися до обговорення 3 питань реалізації Концепції Нової української школи у Скадовському районі за участі О. Савченко - авторки однієї iз програм із реалізації цієї концепції та О. Сухомлинської, адже саме в концепції Нової Української школи було визначено творчій доробок В. Сухомлинського основоположним, системним, перспективним. Провівши аналіз результатів першого року iї втілення, відомі вчені надали поради i рекомендації 3 iї подальшого провадження, окреслили шляхи ефективної підготовки майбутніх викладачів кафедрами університету, зокрема педагогічного факультету.

Отже, співпраця членів бюро Асоціації з науковцями на місцях сприяє визначенню шляхів і можливостей втілення спадщини В. Сухомлинського в практику роботи закладу вищої освіти та загальноосвітньої школи. Такий 


\section{Інноватика у вихованні. Випуск 14. 2021.}

процес $\epsilon$ постійним, науково-методично й організаційно-педагогічно забезпеченим.

Висновки і перспективи подальших розвідок. Отже, дослідження показало, що заходи, які проводить Асоціація Василя Сухомлинського, сприяють вирішенню завдань неперервної педагогічної освіти, об'єднуючи загальноосвітню школу, заклад вищої освіти й установи післядипломної освіти. А відтак, питання втілення ідей В. Сухомлинського в практику роботи закладів освіти Херсонщини різного рівня й типу вирішується як на теоретичному, так i практичному рівні, що $\epsilon$ особливо цінним для підготовки майбутніх фахівців. Науковий пошук засвідчив, що такі кафедральні об’єднання/осередки Асоціації є безпосередніми втілювачами мети й завдань іiі роботи, мають свої особливі завдання, своєрідні зміст і наповнення, реалізують їх на регіональному рівні, що може стати предметом подальших наукових розглядів, зокрема питань діяльності таких дослідницьких центрів сухомлиністів у школах.

\section{СПИСОК ВИКОРИСТАНИХ ДЖЕРЕЛ:}

Программа областной научно-практической конференции, посвященной 70летию со Дня рождения В.А. Сухомлинского - видного советского педагогамылителя и гуманиста. Херсон. $1988.10 \mathrm{c}$.

Програма ХVI Всеукраӥнських педагогічних читань «Василь Сухомлинський у діалозі з сучасністю: иіннісні виміри в освіті». (2009). Херсон. 28 с.

Програма VIII Міжнародної науково-практичної конференції $i$ XXII Всеукраїнських педагогічних читань «Василь Сухомлинський у діалозі $з$ сучасністю: виховуємо культуру потреб особистості». (2015). Херсон. 52 с.

Програма Всеукраӥнського освітнього форуму «Нова украӥнська икола діалог з В.Сухомлинським». (2018). Херсон. 42 с.

Савченко, О. (2008) Всеукраїнські педагогічні читання. Педагогічний пошук. (1). C. 7 .

Савченко, О. (2003) Розвиток сухомлиністики за десять років (1993-2003). Освіта Украӥни. (7 жовт.). С. 6.

Сараєва, О.В. (2007) Педагогічна система В.О. Сухомлинського в науковому доробку вітчизняних учених. Кандидат педагогічних наук. АПН України. 250 с.

Сухомлинська, О.В. (2012). Деякі аспекти еволюції сприйняття творчості В. Сухомлинського: дорога довжиною в 40 років. Історико-педагогічний альманах. №9.

Федяєва, В., Сараєва, О. (2006). Педагогічна система В.Сухомлинського: навчально-методичний посібник. Херсон. 144 с.

Федяєва В.Л. Дитиноцентрична концепція сімейного виховання у науковому доробку В. О. Сухомлинського (2011). Педагогічний дискурс. Вип. 10. С. 496 - 500.

Fedyayeva, V., Goshtonar, I. (2016) Lehrerbildung bei Herbart und Suchomlinski im Vergleich. Wie lernt man erziehen? Zur Didaktik der Padagogik.

\section{REFERENCES}

Programma oblastnoy nauchno-prakticheskoy konferentsii. posvyashchennoy 70letiyu so Dnya rozhdeniya V.A. Sukhomlinskogo - vidnogo sovetskogo pedagogamylitelya $i$ gumanista. [The program of the regional scientific-practical conference dedicated to the 70th anniversary of the birth of V.A. Sukhomlinsky - a prominent Soviet teacher, maker and humanist]. Kherson. 1988. 10p.Kherson. 1988. 10 s. [in Russian].

Prohrama XVI Vseukrainskykh pedahohichnykh chytan "Vasyl Sukhomlynskyi u dialozi z suchasnistiu: tsinnisni vymiry $v$ osviti" [Program of the XVI All-Ukrainian 


\title{
Інноватика у вихованні. Випуск 14. 2021.
}

pedagogical readings "Vasyl Sukhomlynsky in dialogue with the present: value dimensions in education"]. (2009). Kherson. 28 s. (2009). Kherson. 28 s. [in Ukrainian].

Prohrama VIII Mizhnarodnoi naukovo-praktychnoi konferentsii $i$ XXII Vseukrainskykh pedahohichnykh chytan "Vasyl Sukhomlynskyi u dialozi z suchasnistiu: vykhovuiemo kulturu potreb osobystosti». [Program of the VIII International Scientific and Practical Conference and XXII All-Ukrainian Pedagogical Readings "Vasyl Sukhomlynsky in Dialogue with Modernity: Educating the Culture of Individual Needs"]. (2015). Kherson. 52 c. [in Ukrainian].

Program of the All-Ukrainian Educational Forum "New Ukrainian School Dialogue with V. Sukhomlynsky" [Program of the All-Ukrainian Educational Forum "New Ukrainian School - Dialogue with V. Sukhomlynsky"]. (2018). Kherson. 42 c. [in Ukrainian].

Savchenko, O. (2008). Vseukrainski pedahohichni chytannia [All-Ukrainian pedagogical readings]. Pedahohichnyi poshuk. (1). S. 7. [in Ukrainian].

Savchenko, O. (2003). Rozvytok sukhomlynistyky za desiat rokiv (1993-2003) [Development of sukhomlynistyky for ten years (1993-2003)]. Osvita Ukrainy. (7 zhovt.). S. 6. [in Ukrainian].

Saraieva, O. (2007). Pedahohichna systema V.O. Sukhomlynskoho v naukovomu dorobku vitchyznianykh uchenykh [The pedagogical system of V.O. Sukhomlinskyi in the scientific achievements of Ukrainian scientists]. Kandydat pedahohichnykh nauk. APN Ukrainy. 250 s. [in Ukrainian].

Sukhomlynska, O.V. (2012). Deiaki aspekty evoliutsii spryiniattia tvorchosti V. Sukhomlynskoho: doroha dovzhynoiu v 40 rokiv. [Some aspects of the evolution of perception of V. Sukhomlinsky's work: a road in 40 years long]. Istoryko-pedahohichnyi almanakh. No 9. [in Ukrainian].

Fediaieva, V., Saraieva, O. (2006). Pedahohichna systema V.Sukhomlynskoho: navchalno-metodychnyi posibnyk [V. Sukhomlynskyi's pedagogical system: educational and methodical manual]. Kherson. $144 \mathrm{~s}$. [in Ukrainian].

Fediaieva V.L. Dytynotsentrychna kontseptsiia simeinoho vykhovannia u naukovomu dorobku V. O. Sukhomlynskoho [Child-centered concept of family upbringing in the scientific work of VO Sukhomlinsky] (2011). Pedahohichnyi dyskurs. Vyp. 10. S. 496 - 500. [in Ukrainian].

Fedyayeva, V., Goshtonar, I. (2016) Lehrerbildung bei Herbart und Suchomlinski im Vergleich. Wie lernt man erziehen? Zur Didaktik der Padagogik. [in German].

\section{SCIENTIFIC CENTER OF THE VASYL SUKHOMLYNSKYI'S ALL- UKRAINIAN ASSOCIATION AT THE KHERSON STATE UNIVERSITY: FORMATION, ACHIEVEMENTS, DEVELOPMENT PROSPECTS}

\author{
Valentyna Fediaieva \\ Doctor of Sciences (in Pedagogy), \\ Professor, Professor at the prof. E. Petukhova \\ Department of Pedagogy, Psychology \\ and educational management, \\ Kherson State University, \\ Kherson, Ukraine \\ ORCID: 0000-0002-8658-1875, \\ e-mail: Valentina.Fediaieva@gmail.com
}


Candidate of Pedagogical Sciences, Associate Professor, Associate Professor at the Department Theory and Methodology of Pre-school and Primary Education,

Kherson State University, Kherson, Ukraine

ORCID: 0000-0001-7494-1223

e-mail:mriya2211@ukr.net

Abstract. The article presents the analysis of scientific venue's of the AllUkrainian association by Vasyl Sukhomlynskyi activity at the Kherson State University. It shows the venue's achievements and development prospects. The authors have studied the archive materials of the Faculties of Pedagogic and Pedagogical mastery which show the growth of interest towards Vasyl Sukhomlynskyi's scientific heritage in the $70-80$-ies of the XX century. The article is aimed at describing the history of scientific venue of the Vasyl Sukhomlynskyi's All-Ukrainian association - the professor Ye.Petukhov Faculty of pedagogic, philology and educational management, it's findings and practices as well as the development prospects in the system of future teachers training; in the further scientific research of Vasyl Oleksandrovych's and the possibility of his ideas implementation under the conditions of today. Its fulfillment is grounded on the analysis of the scientific results achieved by students, post-graduate students, doctoral students, faculty teachers which are aimed at describing the theoretical and practical aspects of children teaching and education after V. Sukhomlynskyi which was at the highest detail described in the exploratory works of the Vasyl Sukhomlynskyi's All-Ukrainian association The article stresses out that the systematic and most extensive study of Vasyl Sukhomlynskyi's scientific heritage thus providing the development of sukhomlynistics has been achieved due to the active scientific work of students, post-graduate students and doctoral students. Due to the profound and fundamental research (such as Candidate and Doctoral Thesis) we have paid greater attention to the pedagogical personality and to the Vasyl Sukhomlynskyi's practical experience studies in the context of those times educational realia. The Vasyl Sukhomlynskyi All-Ukrainian association together with the Kherson State University teachers have conducted three major scientific events: XVI All-Ukrainian pedagogical readings "Vasyl Sukhomlynskyi in the dialogue with the reality: value dimensions in education". (2009), XXII All-Ukrainian pedagogical readings "Vasyl Sukhomlynskyi in the dialogue with the reality: bringing up the culture of person's needs". (2015) and All-Ukrainian educational forum "New Ukrainian school - the dialog with діалог 3 V. Sukhomlynskyi”. (2018).

Keywords: sukhomlynistics, association, pedagogical readings, pedagogical heritage, scientific venue.

Стаття надійшла до редакиії 14.09.2021p. 